\title{
Uma leitura de La folie du jour, de Maurice Blanchot
}

Davi Andrade Pimentel

\section{Resumo}

Este artigo analisa a narrativa La folie du jour, de Maurice Blanchot, a partir de pontos relevantes do próprio autor em sua concepção de literatura, a saber: a noção de gênero textual, a questão do fragmento, a diferença entre os termos dia e noite, a ideia do neutro, a particularidade do outro e, por fim, a questão do feminino, que está relacionada à questâo da autoria. Além do diálogo entre os textos ficcionais e ensaísticos de Blanchot, este artigo tem como pressuposto teórico textos de Jacques Derrida, Emmanuel Levinas e Christophe Bident. Da leitura da narrativa de Blanchot, constata-se que a ideia de literatura presente em seu texto náo difere da ideia de literatura que se apresenta em seus ensaios críticos, não havendo, portanto, espaços separados de escrita, mas apenas uma escrita blanchotiana.

Palavras-chave: Maurice Blanchot; narrativa; gênero; autoria; outro.

\section{Resumé}

Cet article analyse le récit de La folie du jour, de Maurice Blanchot, en s'appuyant sur des points pertinents de l'auteur lui-même sur sa conception de la littérature, à savoir: la notion de genre textuel, la question du fragment, la différence entre les termes jour et nuit, l'idée du neutre, la particularité de l'autre et, enfin, la question du féminin, qui est liée à la question de l'affectation. Outre le dialogue entre les textes fictionnels et essayistiques de Blanchot, cet article a pour hypothèses théoriques des textes de Jacques Derrida, Emmanuel Levinas et Christophe Bident. A partir de la lecture du récit de Blanchot, il ressort que l'idée de littérature présente dans son texte ne diffère pas de l'idée de littérature présente dans ses essais critiques, n'ayant donc pas d'espaces d'écriture séparés, mais une seule écriture blanchotienne.

Mots-clés: Maurice Blanchot; récit; genre; affectation; autre. 
1. BLANCHOT, Maurice. Le pas au-delà, 1973, p. 66. Todas as traduções das obras em francês citadas neste artigo são de minha autoria.

2. DERRIDA, Jacques. Parages, 1986, p. 267.

3. Ibidem, p. 261-262. Grifos do autor.
Em La folie du jour, narrativa de Maurice Blanchot, as palavras emitem em cada componente discursivo uma pergunta, como se toda a arquitetura textual estivesse associada a uma indagação pertinente: "Como acolher o que sobrevém pela força

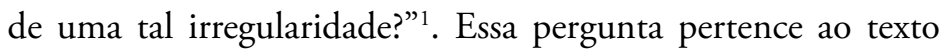
mais teórico de Blanchot, Le pas au-delà; entretanto, toda a obra ficcional de Blanchot a elabora constantemente, como um rito de observância e de completa disponibilidade ao neutro, ao que não pode ser mensurado, afirmado ou negado, embora se afirme como a questáo principal que sempre está em vias de se apresentar para fazer naufragar na mais completa escuridão noturna as palavras que constituem cada sentença das narrativas blanchotianas. Assim se apresenta o texto de La folie du jour, na mais completa indeterminação: "La folie du jour não traz, pois, nenhuma menção de gênero ou de modo."”

Sobre os constituintes formais que surgem antes do teor ficcional de La folie du jour, é imprescindível uma reflexão mais demorada - refiro-me à questão do gênero literário. A narrativa em análise não pertence a um gênero, não há marcação de gênero dada nem pelo autor, nem pela editora responsável por sua publicação. $\mathrm{O}$ texto nos é entregue sem qualquer comprometimento de nomenclatura, sem qualquer marca de domínio/propriedade formal. Com o livro em mãos, o que salta aos olhos é o seu título, o nome do autor e da editora, nenhuma informação a mais nos é dada. Após a primeira etapa da constituição gráfica do livro La folie du jour, temos contato com um amontoado de fragmentos que ora podem ser classificados como pequenos contos, ora como pequenos poemas em prosa - destaque para o belíssimo fragmento poético do "carrinho de bebê". Esses fragmentos também ora convergem na constituição de uma narrativa, ora se dispersam como fragmentos de uma pluralidade inacessível. Derrida, sobre a questão do gênero em $\mathrm{La}$ folie du jour, no texto "La loi du genre", do livro Parages, diz que: "Esse texto [...] parece, pois, feito, entre outras coisas, para fazer pouco de todas as categorias tranquilas da teoria e da história dos gêneros, para inquietar suas seguranças taxonômicas, a distribuição de suas classes e as apelaçóes controláveis de suas nomenclaturas clássicas." ${ }^{3}$

É praticamente instantânea, ao mencionarmos a palavra gênero, a relação que ela estabelece com o significado de que algo está inscrito em um regimento delimitado, mensurável e organizado por regras, ocupando um espaço que lhe é dado nas normatizaçôes previstas e acordadas por um grupo competente, que trabalha exatamente para organizar os algos em suas determinadas prateleiras, com as suas determinadas fichas catalográficas. A palavra gênero compartilha o campo semântico da palavra $l i$ mitação, pois é preciso limitar ou, se preferirmos adicionar um prefixo, delimitar os textos ficcionais para que se possa ter o do- 
mínio, a partir do material organizado, do que se ensina, do que se vende, do que se compra. É necessário limitar para que essa linha de demarcação possa agir como informação do material catalogado, para que esse material não infrinja a lei do que é possível para uns e impossível para outros, do que pode servir para uma determinada faixa etária e não para outra, do que pode ser direcionado a um gênero sexual e não a outro: "Logo que se ouve a palavra 'gênero', logo que ela aparece, logo que se tenta pensá-la, um limite se desenha. E quando um limite vem a se assinalar, a norma e o interdito não se fazem esperar." ${ }^{\prime 4}$ É nesse detalhe classificatório que se oculta uma complexa maquinaria de exclusão, de diferenciação e de rotulação, seja em relação a textos ficcionais, ao gênero humano, a vestimentas, ao acesso a lugares públicos ou privados. Estabelecer o gênero de algo é estabelecer o seu limite, o seu acesso, a sua palavra e o seu público. O gênero, como qualquer elemento limitador, é útil ao mundo, pois é preciso a classificação para que nada escape de uma pretensa ordem que demorou séculos para se estabelecer.

Deve ficar claro que, por mais que o gênero exerça o caráter de exclusão, não nego a sua importância imediata para o mundo, no que se refere à tentativa de convivência pacífica entre os homens, bem como a sua função em estabelecer paradigmas necessários para uma melhor relação entre os homens e a natureza, por mais que a noção de natureza tenda a servir ao interesse humano, desrespeitando as leis de sobrevivência do gênero animal e vegetal. E não sou tão radical em acreditar que $o$ algo possa escapar a um gênero, seja ele qual for. $\mathrm{O}$ que questiono, sobretudo, é o reforço na delimitação, no exaspero em determinar os limites entre os elementos. É preciso que os limites se tornem mais flexíveis e também mais abrangentes, pois a comunicação entre as partes produzirá um acesso múltiplo entre os fatores participantes, bem como a comunicação auxiliará na compreensão do mundo não apenas como um conjunto de elementos enfileirados, diferenciados, mas participantes de uma mesma conjuntura complexa e produtiva. Essa perspectiva de quebra ou de encadeamento dos gêneros não é impossível, pois a literatura, como uma estrutura plural e produzida pelo homem, a confirma. Na questão do gênero, a literatura é fundamental, uma vez que o discurso literário demonstra tanto a fragilidade dos limites que o gênero impóe, quanto a possibilidade de diálogo entre os vários gêneros, dando forma a linguagens multifacetadas e bastante sofisticadas: são discursos poéticos em prosa, crônicas poéticas, romances jornalísticos, dentre muitos outros procedimentos textuais.

Ainda pensando o gênero como classificação, a narrativa de La folie du jour não ambiciona sustentar um arranjo sistemático coeso, termo decisivamente abusivo, não pretendendo, assim, sustentar um único gênero, uma vez que todo o texto se afasta 
5. Ibidem, p. 267.

6. Ibidem, p. 264. Grifos do autor.

7. Ibidem, p. 265. do que é normativo, estável ou previsível para se aproximar da neutralidade da insinuação. Por isso a ausência do gênero na folha de informações do livro blanchotiano: o lugar está vazio não por falta de gênero, mas pelo excesso de gênero. Talvez alguém questione o lugar deixado vazio pelo gênero, afirmando que em outros textos ficcionais de Blanchot a marca do gênero aparece, estando presente como informação a mais ao leitor. No entanto, em se tratando das narrativas ficcionais de Blanchot, a classificação do gênero é mais uma questão que envolve o seu discurso, pois, em sua maioria, essas narrativas tematizam metalinguisticamente o processo de elaboração literária, as indagaçóes que assolam o escritor, como também retratam a angústia do escritor que se sabe impotente em face de sua obra. Por essa razáo, quando o gênero literário ocupa um lugar na folha de informaçóes do livro de Blanchot, é interessante pensá-lo como uma problemática a mais, pois, nesses livros com os gêneros nomeados, o texto não somente reflete sobre essa catalogação como rompe com os limites impostos pelo gênero literário previamente afirmado.

E, a título de informação, "aconteceu mais de uma vez a Blanchot modificar a menção de gênero, de uma versão a outra ou de uma ediçấo a outra." 5 não apenas o autor joga com a definição catalográfica de sua narrativa, trazendo uma multiplicidade de questóes que serão postas em dialogo com o texto, como o próprio texto se exonera de qualquer arroubo classificatório, pois o discurso literário blanchotiano aprecia a sua autonomia, a sua própria lei, a sua própria atemporalidade. Anteriormente, afirmei que a narrativa de La folie du jour náo pertence a um gênero, embora, logo em seguida, tenha afirmado que não existe algo que se furte a uma classificação de gênero. É verdade, a narrativa de Blanchot náo pertence a um gênero, ela participa de vários gêneros: "um texto não saberia pertencer a nenhum gênero. Todo texto participa de um ou de vários gêneros, não existe texto sem gênero, existe sempre gênero e gêneros, mas essa participação não é nunca uma pertença." ${ }^{\prime 6} \mathrm{Com}$ sua indeterminação de gênero, a narrativa de La folie du jour instaura a instabilidade discursiva que acompanhará toda a constituição de sua arquitetura textual. Nesse primeiro momento, qualquer pretensão de classificar esse texto se mostrará refutável e discutível. Retomo a fala radical e irônica de Derrida: "Eu não direi esse drama, essa epopéia, esse romance, essa novela ou essa narrativa, sobretudo essa narrativa"'

Decorrida a questão do gênero, entro no espaço ficcional de La folie du jour, cuja estrutura narrativa é edificada a partir de fragmentos, semelhante à estrutura de dois livros teóricos de Blanchot: Le pas au-delà e L'écriture du désastre. O fragmento, na concepção blanchotiana, está associado ao neutro. Mas, antes de qualquer interpretação, é necessário compreendermos o fragmento não apenas como fator de desestruturação, de quebra ou 
de rompimento entre as partes: "Não mais poder escrever senão em relação com o fragmentário, isso não é escrever por fragmentos, salvo se o fragmento é ele mesmo sinal para o fragmentário." ${ }^{8} \mathrm{Um}$ texto fragmentado não é apenas aquele que possui as suas partes dispersas, mas aquele que traz em sua composição a indeterminação de seus constituintes - o fragmentário tanto pode estar relacionado ao texto fissurado, quanto ao texto uniforme, uma vez que a essência do fragmentário não está somente associada à estrutura formal de um texto, mas está, sobretudo, associada à impossibilidade de estabelecer padróes para a compreensão desse texto. $\mathrm{O}$ fragmentário é a impossibilidade do texto servir para, é a impossibilidade de se inscrever uma verdade, um saber ou um padrão no discurso de um texto ficcional. O fragmentário é o que não pode ser determinado, classificado ou delimitado. O fragmentário é o neutro: "Pensar o fragmentário, pensá-lo em relação com o neutro, um e outro parecendo se pronunciar juntos, sem comunidade de presença e como no exterior um do outro"'. É a partir da perspectiva do fragmentário e do neutro que a narrativa La folie du jour se inicia.

Na página inicial, após um breve espaço em branco, o que nos convida a pensar desde já no espaço do silêncio blanchotiano, lemos o primeiro fragmento de La folie du jour:

Não sou nem sábio nem ignorante. Conheci alegrias. É muito pouco dizer: vivo, e essa vida me dá o maior prazer. Então, a morte? Quando eu morrer (talvez daqui a pouco), conhecerei um prazer imenso. Não falo do gosto antecipado da morte, que é insosso e frequentemente desagradável. Sofrer é embrutecedor. Mas tal é a verdade notável da qual estou seguro: experimento ao viver um prazer sem limites e terei ao morrer uma satisfação sem limites. ${ }^{10}$

O narrador, ao dizer que não é nem sábio nem ignorante, inscreve o seu discurso na particularidade do neutro. $\mathrm{O}$ neutro, a partir de uma concepção já enraizada em nossa cultura, é o ser que não toma partido. Contudo, quando a palavra neutro passa a participar dos textos ensaísticos blanchotianos ou quando Blanchot faz uso dessa palavra em suas narrativas, o leitor deve estar atento, pois é preciso remover os conceitos que se aderem ao neutro, que fazem dele uma palavra já cristalizada socialmente, para que se possa estar aberto à nova concepçáo de neutro explorada por Blanchot. E lembro que na obra blanchotiana muitas palavras devem ser cuidadosamente interpretadas, como as palavras silêncio, desastre, passividade, noite, dia, esquecimento e morte. Nos textos de Blanchot, o neutro, longe de estabelecer um posicionamento de ser inerte, é ativo, como afirma Christophe Bident, no texto "Les mouvements du neutre", da Revista Alea: "É preciso, pois, repetir que o neutro de Blanchot, bem como aquele de Barthes, é uma noção ativa." 11
8. BLANCHOT, Maurice. Le pas au-delà, 1973, p. 61.

9. Ibidem, p. 61-62.

10. BLANCHOT, Maurice. La folie du jour, 2002, p. 9.

11. BIDENT, Christophe. "Les mouvements du neutre". Revista Alea, 2010, p. 14. 
Por não ter uma característica definida, sempre escapando a toda medida de conceitualização, embora não escape de uma reflexão considerável, o neutro blanchotiano produz naturalmente um questionamento por desafiar as estruturas básicas de compreensão que não atendem às suas especificidades mais elementares, como, por exemplo: a possibilidade de nada escolher, mas de optar pela possibilidade de ter acesso, ao mesmo tempo, ao sim e ao não reunidos; de se afastar do previsível e ir ao encontro do jamais pensado; de desejar se expressar pela palavra ainda não ouvida; de ter acesso ao não acessível; e de poder pensar sem uma finalidade, sem ter o dever de escolher (dialética) para poder continuar a refletir. Nesse ponto, a literatura converge para o espaço da neutralidade, da possibilidade. Ou seja, o neutro, ao se tornar questão, coloca a literatura, também, em discussão. Qual a finalidade, qual a intenção, qual o objetivo do texto literário? A essas questôes, a literatura responde através de seu próprio discurso. Quando o narrador diz: "Não sou nem sábio nem ignorante", ele não apenas se coloca no espaço do neutro, da não dialética, mas, sobretudo, traz a questáo da neutralidade para ser dialogada em sua narrativa.

O nem... nem... blanchotiano apresenta o neutro em seu discurso sem apresentá-lo realmente. É o estar presente ainda por vir, uma vez que a frase neutra está materializada, mas não consolidada. Nós podemos analisá-la, dispor dela como desejarmos, porém, não há a definição do que o personagem é ou virá a ser, pois a escolha que o caracteriza está além de seu próprio discurso, além da narrativa que se encontra no espaço da neutralidade. O neutro se afirma a partir de sua ausência, a partir de um espaço por vir - neutralidade que atinge outras estruturas do texto blanchotiano, influenciando radicalmente na postura do narrador. Aquele que narra não se determina através de um nome, ele é um ser anomeado ou náo nomeado — por optar pela transgressão do neutro, o personagem se afasta da demarcação oferecida pelo nome, como ele igualmente se afastará da definição de escritor que narra a sua própria história, que pode ser conferida pelo título de La folie du jour.

Um segundo traço que faz da narrativa uma aproximação com o neutro é o modalizador talvez, que a indetermina, que faz do discurso do narrador não uma afirmação, mas uma possibilidade. $\mathrm{O}$ talvez concede ao material narrado uma incerteza que dialogará com o final imprevisto da narrativa. E juntamente com o talvez está a ideia da morte em duas perspectivas: ora a morte entendida enquanto fim, como constatamos no seguinte trecho: "Quando eu morrer (talvez daqui a pouco), conhecerei um prazer imenso", ora a morte na perspectiva do morrer, que se diferencia da primeira ideia de morte porque o morrer é ainda continuar a viver, é náo ter acesso ao fim que poria um ponto final em seus sofrimentos: "Sofrer é embrutecedor". A última 
constituição frasal do fragmento em análise dialoga com a sua primeira frase, apontando uma outra perspectiva do neutro, não o que se afasta, mas o que se afirma em duas posiçóes dissonantes, desejando as possibilidades a ele disponíveis. É o sim... sim... que, ao lado do nem... nem..., apresenta o neutro: "Mas tal é a verdade notável da qual estou seguro: experimento ao viver um prazer sem limites e terei ao morrer uma satisfação sem limites". O sim... sim... terá um papel fundamental na narrativa, pois está associado ao feminino, ao gerar, ao produzir. Seguindo a leitura da narrativa, lemos outro fragmento:

Minha existência é melhor que a de todos? É possível. Tenho um teto, muitos não têm. Não tenho lepra, não sou cego, vejo o mundo, felicidade extraordinária. Eu a vejo, essa luz fora da qual náo existe nada. Quem poderia me tirar isso? E essa luz se apagando, me apagarei com ela, pensamento, certeza que me transporta. ${ }^{12}$

Nesse terceiro fragmento, de acordo com a ordem de sua aparição no texto blanchotiano, é perceptível a presença de um segundo interlocutor na pergunta retomada e repetida pelo narrador sobre a sua existência. Ao longo da leitura dos fragmentos blanchotianos, constata-se como, em praticamente todos eles, há a presença de um segundo personagem que ganha voz através da repetição de suas perguntas retomadas pelo narrador no relato de sua narrativa. $\mathrm{O}$ processo narrativo se origina em boa parte pelas perguntas lançadas por um outro ao narrador, que, nos fragmentos finais, se corporifica na figura de dois médicos. E a resposta, que parecerá um tanto compreensível em sua comparação, já insinua a relação que o narrador manterá com o outro, uma relação de contrastes. Mas o que se sobressai, nesse fragmento, é a relação que o personagem diz manter com o dia a partir de sua alardeada felicidade em ver o mundo, em poder enxergar o mundo através da luz do dia.

Emmanuel Levinas, em "Exercices sur La folie du jour", no livro Sur Maurice Blanchot, define essa "felicidade extraordinária" como processo de estabilidade: "O que é, pois, a felicidade? A estabilidade - a positividade - do mundo posto antes de toda tese, repouso atrás de toda agitação e de todo desejo e que suporta - ou engloba ou compreende - toda absurdidade"13. A absurdidade do mundo é a sua formação em desastre, é a precária ordenação que faz dos homens seres que se acreditam apoiados por uma estrutura regida por leis que os protegem. No entanto, não há leis suficientes que possam demarcar, por exemplo, a linguagem utilizada como instrumento para a organização do mundo. A linguagem é arbitrária, logo, falha, não servindo para. E se a linguagem não ordena o mundo, sendo a linguagem o modo pelo qual o mundo tende a se organizar, a debilidade do mundo se deixa entrever. E nessa absurdidade se encontra, no momento, o personagem.
12. BLANCHOT, Maurice. La folie du jour, 2002, p. 10.

13. LEVINAS, Emmanuel. Sur Maurice Blanchot, 2004, p. 60-61. 
14. Ibidem, p. 11.

15. BLANCHOT, Maurice. La folie du jour, 2002, p. 10.

16. BLANCHOT, Maurice.

L'écriture du désastre, 1980, p. 78.
Nos textos de Blanchot, ficcionais ou ensaísticos, a palavra dia está relacionada à norma, ao poder, à verdade, à estabilidade, à objetividade e à razáo - elementos que dialogam com a alienação que estabelece a ordem no mundo. Elementos que, por suas características, não compactuam com o literário ou com a noite. O dia, com sua luz que torna claro o antes escuro, é a ordem que prospera no mundo, é a regra, a lei. O dia é o identificável, é o não neutro. Nas palavras de Levinas, o dia na compreensão blanchotiana é "o Mundo, o Poder, a Ação, em que se aloja toda a extensão do Humano" ${ }^{14}$. É seguindo essa noção de dia que o narrador se diz totalmente integrado ao mundo, a "essa luz fora da qual náo existe nada". Nesse momento, a relação do narrador com o mundo é de total harmonia, embora a segunda pergunta - "Quem poderia me tirar isso?" — anuncia desde já o declínio do idílio solar, o qual nós veremos no fragmento seguinte. A luz do dia é tornada desarmônica, falsa. No próximo fragmento, é notória a mudança de tom do narrador, a sua voz ganha uma angústia e um desespero que não sentíamos nos fragmentos anteriores. A relação estável com o dia, com a estrutura que o comportava, se torna matéria de reflexão:

Amei os seres, os perdi. Tornei-me louco quando essa pan-
cada me marcou, pois é um inferno. Mas minha loucura
ficou sem testemunha, meu extravio não aparecia, apenas
minha intimidade estava louca. Às vezes, me tornava fu-
rioso. Diziam-me: Por que você está tão calmo? Porém, eu
estava queimado dos pés à cabeça; à noite, corria pelas ruas,
berrava; de dia, trabalhava tranquilamente. ${ }^{15}$

A estabilidade mantida nos outros fragmentos é rompida, algo se quebra, se deflagra como relação impossível. O primeiro traço da loucura que observo no relato do personagem advém da perda dos seres, ou melhor, da perda da relaçáo que ele mantinha com as outras pessoas, embora o narrador náo comente a que tipo de perda se refere e nem mesmo como ocorreu essa perda. A supressão das informaçóes, como é própria aos fragmentos, deixa em suspenso os motivos que o levaram a perder o contato com os seres, bem como não me autoriza simplesmente a pensar essa pancada como metáfora, pois, em alguns fragmentos posteriores, sabemos que um homem o feriu com uma faca, o que pode muito bem vir a ser essa pancada sofrida por ele. Esse golpe deixa transparecer a incompatibilidade que marcará a relação contrastiva entre o narrador e o outro. $\mathrm{O}$ fragmento do golpe sofrido pelo narrador marca, também, a estrutura fragmentada/golpeada de sua narrativa, violência entre corpos de escrita: "A escrita é já (ainda) violência: o que existe de ruptura, de quebra, de despedaçamento, o rasgão do rasgado em cada fragmento, singularidade aguda, ponta afiada." ${ }^{16}$ Ressalto que o 
relato proferido pelo narrador perpassa a linha tênue que separa o metafórico do real, um relato que se indetermina de tal maneira que faz os sentidos se multiplicarem igualmente a um prisma. A perda da relação com o outro, na perspectiva de Levinas, é um dos efeitos sofridos pelo personagem quando se conscientiza da debilidade do dia, quando, na visão mais apurada da realidade em que se situa, o outro não é mais o ser que acolhe ou o ser que lhe é identificável, mas o separado, aquele que participa ainda da relação estável com o mundo.

Assim, o narrador se vê sozinho na compreensão do dia como farsa e isso "é um inferno". O inferno que é a consciência de se saber sozinho, de ter a sua loucura sem testemunha, de ter o seu extravio tornado imperceptível, somente sentido por ele, ninguém mais. $\mathrm{O}$ inferno se converterá em abertura para a real composição da narrativa: o caráter imediato do tempo que dará ao texto um tom de náo exterioridade. Sem exterioridade, a narrativa se repete, se repetindo e se fixando no ato presente daquele que a narra. A estabilidade do dia se repete, como também se repete a sua queda: "A estrutura do presente, do atual, do Hoje, é assim? O infernal." ${ }^{17} \mathrm{Na}$ situação infernal, o outro não mais o compreende, e essa não compreensão, à medida que os fragmentos são lidos, se acirra, tendo como consequência o levante de desespero do outro que apunhala o narrador sem entender o porquê de tal investida. A única saída que resta ao narrador é a noite. A noite é o único modo que o personagem encontra para extravasar a consciência da perda, a consciência do dia como perda. E qual é o resultado de se saber preso em um mundo que não o protege, que se estrutura em bases movediças e enganosas?

a felicidade em sua própria permanência se obceca, a explosão em loucura se fecha em loucura, em opressão, em irrespirável interioridade sem exterior. [...] A extrema consciência seria a consciência do sem saída e assim não o exterior, mas a ideia do exterior e, assim, obsessão. Um exterior pensado na impossibilidade do exterior, o pensamento produzindo o desejo do impossível exterior. ${ }^{18}$

A obsessão pelo exterior se configura na noite. A noite se apresenta, no fragmento blanchotiano em análise, como a necessidade de uma saída, de um exterior, que, na verdade, não é possível tocar, se aproximar: "à noite, corria pelas ruas, berrava". No deslocamento efetuado pelo narrador, a noite é o espaço da possibilidade, do indeterminado, que se opóe ao espaço da organização do dia. A noite, na leitura blanchotiana, é o "Velar sobre o sentido ausente" 19 . O espaço noturno se revela como o espaço em que a literatura pode transgredir através da palavra poética. A noite é o espaço do abominável, é por onde o escritor vaga sem rumo, sem direção, é a escrita que não se efetiva em norma
17. LEVINAS, Emmanuel. Sur Maurice Blanchot, 2004, p. 60.

18. Ibidem, p. 63.

19. BLANCHOT, Maurice.

L'écriture du désastre, 1980, p. 72. 
20. Ibidem, p. 67.

21. BLANCHOT, Maurice. La folie du jour, 2002, p. 12. ou em verdade. A noite é o espaço da ausência, que se configura como pluralidade, é o deserto plural, é o excesso por onde a palavra transborda o seu sentido multifacetado.

A noite é, segundo Blanchot, o espaço do neutro, da morte, do texto sem sentido de verdade, da explosão da luz noturna, escurecida, sem entendimento, espaço da produtividade literária, do descompasso do texto, da ambiguidade que assola a narrativa, fazendo dela um experimento metapoético, em que a própria narrativa desenvolve uma série de complexas reflexóes sobre si mesma, sobre a própria estrutura literária, sobre as suas perdas, sobre as suas desilusões, sobre as suas loucuras. É a noite, num sentido muito mais amplo do que posso nomear, significar, que desafia os escritores, bem como é a noite que trará do mar Thomas, de Thomas l'obscur - o personagem mais obscuro de Maurice Blanchot: "A luz brilha - brilho, o que, na claridade, se clama e não aclara (a dispersão que ressoa ou vibra até ao deslumbramento). Brilho, o ressoo quebrante de uma linguagem sem acordo." 20

No oitavo fragmento, lemos:

No entanto, encontrei seres que nunca disseram à vida, cala-te, e nunca à morte, vai-te. Quase sempre mulheres, belas criaturas. Os homens, o terror os sitia, a noite os atravessa, eles veem seus projetos aniquilados, seu trabalho reduzido ao pó, eles ficam estupefatos, eles tão importantes que queriam fazer o mundo, tudo sucumbe. ${ }^{21}$

Os seres que dizem $\operatorname{sim} . .$. sim... tanto à vida quanto à morte são as mulheres, ou melhor, como diz o narrador, quase sempre são as mulheres que se afirmam na neutralidade da escolha. Notemos o caráter ético do discurso blanchotiano ao não afirmar que são todas as mulheres, mas algumas, utilizando-se do modalizador quase, que, juntamente com o talvez, faz da narrativa um fluxo de indeterminaçáo inerente ao neutro. O feminino é o neutro. Em minha leitura, um segundo ser também se faz afirmador, também diz sim... sim.... Esse ser é o narrador, quando diz, no primeiro fragmento, sim...sim... à vida e à morte. E, como o narrador nos lembra, o sim... sim... é da ordem do feminino. Desse modo, o personagem, mesmo na categoria do masculino, participa da categoria do feminino. Ele, também, uma bela criatura:

Porém, eu mesmo, que não "sou nem sábio nem ignorante", "experimento ao viver um prazer sem limite e terei ao morrer uma satisfação sem limite". Nessa presunção aleatória que liga a afirmação quase sempre às mulheres, e belas, é, pois, mais que provável que, na medida em que eu diga sim, sim, eu seja mulher, e bela. Eu sou mulher, e bela. O sexo gramatical (ou também anatômico, em todo caso o sexo submetido à lei da objetividade), o gênero masculi- 
no é então afetado pela afirmação por uma deriva aleatória que pode sempre fazê-lo outro. Existiria ali uma espécie de acasalamento secreto, um hímen irregular, um casal irregular, pois nada disso pode ser regido por uma lei objetiva, natural ou civil. O "quase sempre" é a marca desse hímen secreto ou irregular, desse acasalamento que é também talvez mistura de gêneros. Os gêneros entram um no outro. E não nos proibirão de acreditar que entre essa mistura de gêneros como loucura da diferença sexual e a mistura de gêneros literários exista alguma relação. ${ }^{22}$

A transgressão dos gêneros nos leva a pensar o ato literário como gerador, como o processo que dá origem a algo, nesse caso, ao discurso literário. $\mathrm{O}$ feminino, seguindo essa perspectiva, tem parte em todo escritor que se envolve no processo de dar à luz uma narrativa. Seguindo esse raciocínio um pouco mais longe, o feminino pode ser interpretado como a própria literatura, pois ela é o neutro e a indeterminação - características próprias das belas criaturas. $\mathrm{O}$ feminino e a literatura se relacionam não apenas no modo de gerar, mas, sobretudo, na questão da escrita literária como devir, uma vez que a significação da palavra mulher - diferente da significação da palavra homem, e isso é salientado pelo narrador - revela um ser que não se impóe, que náo alimenta uma verdade como poder, que não se encontra como formadora de verdades definitivas. Essas características não fazem da significação da palavra mulher uma significação menor, e sim uma significação mais imponente do que possa parecer, associada de imediato à palavra poética, à fala essencial blanchotiana:

A fala essencial é, nesse aspecto, o oposto. Por si mesma, ela é imponente, ela impóe-se, mas nada impóe. Muito longe também de todo o pensamento, desse pensamento que repele sempre a obscuridade elementar, pois o verso "atrai não menos que afasta", "aviva todos os jazimentos esparsos, ignorados e flutuantes": nele as palavras voltam a ser "elementos", e a palavra noite, apesar de sua claridade, ganha intimidade com a noite. ${ }^{23}$

O narrador dará à luz um texto, por mais que esse texto seja negado por ele no último fragmento de La folie du jour, pois o narrador é incapaz, enquanto escritor, diz ele, de dar à luz qualquer narrativa. Essa suposta incapacidade de poder construir uma história indica a característica do narrador em não se colocar numa estrutura previamente estabelecida, em não se enquadrar na definição de escritor. Claro que, ao negar a sua obra, o narrador negará a si mesmo enquanto narrador, dando ao texto blanchotiano uma característica inovadora. Do lado do feminino, as mulheres saúdam o narrador como aquele que deve ser respeitado, como a grande fêmea: "As mulheres se deitavam
22. DERRIDA, Jacques. Parages, 1986, p. 279-280.

23. BLANCHOT, Maurice.

O espaço literário, 1987, p. 33. 
24. BLANCHOT, Maurice. La folie du jour, 2002, p. 13.

25. Ibidem, p. 14.

26. LEVINAS, Emmanuel. Sur Maurice Blanchot, 2004, p. 68. no chão para me dar a máo"24. Uma fêmea que se diferencia do homem, do homem enquanto entidade do mundo, enquanto símbolo do poder, das leis, da verdade.

$\mathrm{O}$ narrador, por não ter com quem compartilhar a revelação infernal, permanece distanciado, sozinho. A cadência da precipitação violenta, que marcará o narrador e que, depois, como leremos, será o real motivo de seu relato, tem como resultado um golpe de faca sofrido por ele. Esse golpe também revela metaforicamente o golpe que sofre aquele que náo se enquadra no espaço das leis vigentes, o pária que náo encontra afinidade com os demais habitantes que compartilham com ele o espaço que ocupa. A faca é a precipitação do estranhamento, é a imposição do afastamento, como observamos no décimo segundo fragmento:

Não sou receoso, recebi pancadas. Alguém (um homem exasperado) me tomou a máo e plantou a sua faca nela. Tanto sangue. Depois, ele tremia. Ele me oferecia sua mão para que eu a pregasse sobre a mesa ou contra uma porta. Porque ele me tinha feito esse corte, o homem, um louco, se acreditava tornado meu amigo; ele empurrava sua mulher nos meus braços; ele me seguia nas ruas gritando: "Estou condenado, sou o joguete de um delírio imoral, confissáo, confissáo." Um estranho louco. Durante esse tempo, o sangue pingava em meu único terno. ${ }^{25}$

Nós reconhecemos o outro a partir do momento em que nós nos vemos e nos reconhecemos no outro, nos reconhecendo a nós mesmos. Esse reconhecimento é mais uma forma de, no outro, buscarmos uma interpretação para os nossos atos. Assim, quando nos reconhecemos no outro, o outro passa a existir, passa a se tornar visível. Contudo, a facada é o caminho oposto da identificaçáo, pontuando a dissimetria que se inscreve entre o narrador e o outro. Não há mais o caminho da compatibilidade, pois somente o narrador se dispóe a ver o mundo de uma forma diferenciada, enquanto o outro permanece disposto na ilusão do idílio solar, na segurança falsa das leis e da ordem. O narrador, como um vírus que invade um corpo sadio, é golpeado por um suposto anticorpo. A mão que pede ajuda, implorando por uma concordância, é golpeada. Qualquer movimento de hospitalidade lhe é negado. Nesse momento, é mais do que clara a oposição entre o narrador e o outro.

Na leitura de La folie du jour, Levinas compreende a necessidade do narrador pela compreensão do outro como mais uma possibilidade de saída que ele intenta obter na relação de acolhimento que manteria com o outro, caso pudesse dividir com ele a conscientização do mundo em ruína: "Relação com outrem - última saída. De uma ponta a outra da narrativa essa relação se rememora." ${ }^{26}$ Possibilidade de saída que não se efetiva. É importante ressaltar que, mesmo após o golpe sofrido, ainda 
permanece no narrador o desejo de cumplicidade com o outro. Esse desejo é retomado no décimo sexto fragmento, quando o narrador observa um carrinho de bebê e mais uma vez reaparece nele a esperança de uma nova possibilidade de contato com o outro, uma possibilidade de acolhimento proporcionado pelo dar o passo, dar a passagem:

Do lado de fora, tive uma curta visão: havia a dois passos, justo na esquina da rua que eu devia deixar, uma mulher parada com um carrinho de bebê, eu apenas a avistava muito mal, ela manobrava o carrinho para fazê-lo entrar pelo grande portáo. Neste instante entrou por esse portáo um homem que eu não tinha visto se aproximar. Ele já tinha atravessado a entrada quando fez um movimento para trás e tornou a sair. Enquanto ele se mantinha ao lado do portão, o carrinho de bebê, passando diante dele, levantou-se levemente para transpor a entrada e a jovem mulher, depois de ter levantado a cabeça para olhá-lo, desapareceu por sua vez. ${ }^{27}$

Nesse fragmento extraordinário, todo construído pelo não dito e pelo subversivo, o poético se faz ao acaso, na perdida troca de olhares entre um homem e uma jovem mulher, ambos desconhecidos, mas aproximados por uma situação de completa cumplicidade. A esperança do narrador é retomada ao observar o movimento do carrinho de bebê, que, por um motivo desconhecido, não ultrapassa direito a entrada, fazendo com que um homem, que já tinha entrado no ambiente em que desejaria entrar a jovem, retornasse e, nesse retorno, em que sentimos a cumplicidade entre os seres, a identificação mútua, cedesse o passo, concedendo à mulher a passagem. Nessa passagem, há a presença do fálico, do desejo daquele que pode ceder para deixar entrar o outro, e o outro corresponde à passagem aberta, deixando-se penetrar no local antes impossibilitado pela entrada. Nesse fragmento em que o fálico está para a passagem assim como a passagem está para o fálico, o narrador observa uma possibilidade de ainda ter com o outro um traço de cumplicidade, de identificação, pois "a jovem mulher, depois de ter levantado a cabeça para olhá-lo", olhar o homem que lhe cedeu o passo, está para o homem assim como o homem está para ela. Ou seja, ambos ainda compartilhando de uma parceria mútua:

É a pequena cena em que, diante de um grande portão, um homem cede o passo a um carrinho de bebê, que é o acontecimento no qual alguma coisa advém — ou seja, advém "sem convir" - um se retira diante do outro, um está para o outro. Daí a alegria do narrador. Ela parece elevá-lo acima do ser. ${ }^{28}$

A alegria do narrador é provocada pela relação que se estabelece entre o casal, relação que antes ele havia perdido e que o
27. BLANCHOT, Maurice. La folie du jour, 2002, p. 16.

28. LEVINAS, Emmanuel. Sur Maurice Blanchot, 2004, p. 68.

Grifos do autor. 
29. BLANCHOT, Maurice. La folie du jour, 2002, p. 17.

30. Ibidem, p. 17.

31. LEVINAS, Emmanuel. Sur Maurice Blanchot, 2004, p. 63.

32. Ibidem, p. 72.

33. BLANCHOT, Maurice. $L a$ folie du jour, 2002, p. 18.

34. Ibidem, p. 28. impulsionava a ver o dia em sua realidade: um dia louco, despropositado, de falsas claridades. Esse estado de alegria se confunde com o gozo sexual, proporcionando ao narrador um estado de pura dispersão e de delírio, acreditando que o dia finalmente findaria - tanto o dia que finda para a chegada da noite, quanto o dia que finda enquanto lei absurda: "Essa curta cena me elevou até ao delírio. Eu não podia provavelmente explicá-la toda e, no entanto, estava seguro, tinha apanhado o instante a partir do qual o dia, tendo se deparado com um acontecimento verdadeiro, ia se apressar em direção ao seu fim." ${ }^{29}$ Entretanto, $o$ passo oferecido à mulher na cumplicidade daquele que se identifica e, ao se identificar, deseja, bem como o espaço em que essa identificação ocorre, não mais pertence ao narrador, pois esse passo ocorre à luz do dia, à luz do mundo, espaço interditado ao personagem por ele permanecer fora da norma, por ele perceber o dia em sua alegoria enganosa.

No estado ainda de gozo, o narrador espreita, de uma fresta do muro, uma casa, em que estava provavelmente o casal, compartilhando com os demais seres de uma cumplicidade pertencente àqueles que se identificam. Casa que, pela distância do pátio, distância obscura e pouco nítida, se afasta do narrador, imputando-lhe metaforicamente uma proibição, como também o alertando de que, no outro, ele não encontrará saída - o narrador se encontra sozinho: "Fui a essa casa, mas sem entrar lá. Pelo orifício, via o começo escuro de um pátio. Apoiei-me no muro pelo lado de fora, tinha decerto muito frio; o frio me

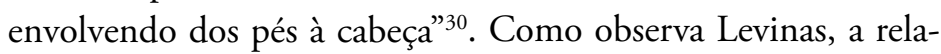
ção conflituosa entre o narrador e o outro é retomada em grande parte dos fragmentos. É uma relação sempre rememorada como possibilidade de poder tocar o exterior, de experimentar o fora, de se saber liberto do que intenta fazer dele um ser servil. A consciência do mundo em ruína se revela, consequentemente, em uma grande obsessão pelo fora: "A consciência extrema é obsessão, asfixia, opressão, esmagamento contra um muro." 31

Definitivamente, para o narrador, não há saída: “Outrem — o único ponto no qual se abre um exterior — não tem saída." ${ }^{32}$ Do mesmo modo como alguém apunhala o narrador com uma faca, é novamente um alguém que fere os seus olhos: "Quase perdi a vista, pois alguém esmagou vidro sobre meus olhos. Essa pancada me abalou, eu reconheço." ${ }^{33}$ É por esse motivo, na busca por encontrar o infrator desconhecido, que o relato do narrador é originado. A razáo pela qual lemos a narrativa La folie du jour decorre de um possível interrogatório, em que dois médicos exigem do narrador um relato do acontecido em seus detalhes, porém, ele será incapaz de relatar os fatos como desejavam os médicos: "Quem jogou vidro em seu rosto? Essa questão voltava em todas as questôes. ${ }^{34} \mathrm{O}$ discurso do narrador tem como base o outro, pois praticamente todo o seu relato tem 
como impulso o movimento deflagrado por um alguém - o relato somente existe através do outro. A quase cegueira resultaria do excesso de saber que o narrador sustenta sobre o dia, sobre como é desestruturada a ordem do mundo e como o dia é louco em sua constituição. É por se aproximar muito da luz do dia, interpretando-a, investigando-a, dissecando-a, que o narrador tem a vista golpeada. É o excesso de luz que faz dele um quase cego: "Que essa abertura da verdade — que essa claridade — atingindo a transparência do vazio - pudesse ferir a retina como um vidro que se quebra sobre o olho do qual ele aguça a vista e que essa ferida seja, no entanto, procurada como lucidez e sobriedade, eis novamente a loucura do dia." ${ }^{35}$

Com os olhos feridos, o dia passou a afligi-lo, pois a luz retirou o sentido mais importante que lhe permitia ainda continuar a procurar uma saída: "O pior era a brusca, a terrível crueldade do dia, não podia nem olhar nem não olhar; ver era o pavor, e cessar de ver me dilacerava da testa à garganta. ${ }^{36}$ A necessidade do narrador em continuar a olhar a luz do dia para se manter protegido e para tentar alcançar a possibilidade de fuga o machucava. No entanto, deixar de olhar o dia lhe era praticamente impossível, pois a sua possibilidade de fuga dialogava com a sua possibilidade de ver a claridade solar. Com os olhos feridos, o personagem escuta um animal acuado, cujo perfil era análogo ao seu: "Além disso, ouvia gritos de hiena que me colocavam sob a ameaça de uma besta selvagem (esses gritos, acredito, eram os meus)." 37

No período de sua recuperação, a lei, no vigésimo nono fragmento, surge para que o narrador lhe conte quem feriu seus olhos:

Atrás de suas costas [dos médicos], eu avistava a silhueta da lei. Não a lei que se conhece, que é rigorosa e pouco agradável: essa era outra. Longe de cair sob sua ameaça, era eu quem parecia assustá-la. Se fosse acreditar nela, meu olhar era o raio e minhas mãos ocasióes de perecer. Além disso, ela me atribuía ridiculamente todos os poderes, ela se declarava perpetuamente a meus joelhos. Mas ela não me deixava perguntar nada e quando ela tinha reconhecido o meu direito de estar em todos os lugares, isso significava que eu não tinha lugar em nenhuma parte. Quando ela me colocava acima das autoridades, isso queria dizer: você não está autorizado a nada. Se ela se humilhava: você não me respeita. ${ }^{38}$

Apenas a silhueta da lei se manifesta. Não é o todo da lei que se distingue, mas somente um fio de presença, algo que se dissipa, que está no instante em que não está. Não sendo exclusivamente a lei de que tomamos conhecimento no mundo, essa lei, lei do totalmente diferente, é a lei também da literatura. Lei do texto proferido pelo narrador, lei que seduz não
35. LEVINAS, Emmanuel. Sur Maurice Blanchot, 2004, p. 64.

36. BLANCHOT, Maurice. $\mathrm{La}$ folie du jour, 2002, p. 18.

37. Ibidem, p. 18.

38. Ibidem, p. 24. 
39. DERRIDA, Jacques. Parages, 1986 , p. 284.

40. Ibidem, p. 281.

41. BLANCHOT, Maurice. La folie du jour, 2002, p. 27. apenas para fazê-lo voltar à ordem do dia, que, aqui, definha, mas sedução que origina a linguagem, que origina o relato. Lei do literário. Lei do feminino: "A lei, em seu elemento feminino, é uma silhueta que joga" ${ }^{39}$. Por sabermos que o perfil projetado atrás das costas dos médicos é, por sua vez, o espectro do dúbio, nós compreendemos melhor o temor que a lei sente ao se aproximar daquele que a originou. Antes do fim da narrativa, quem estabelece as leis da narração é o narrador de La folie du jour. Todos devem temê-lo, todos dependem dele enquanto o texto não finaliza, enquanto a elaboração continua o seu passo errante. A constante ameaça é o narrador: "era eu quem parecia assustá-la”. Em seguida, após um breve momento de reconhecimento, se inicia o jogo sarcástico da lei. Ela atribui regalias e poderes ao narrador, sabendo, por ser a lei da narrativa, que esses atributos, sugeridos como dons dados por ela, na verdade, eram os dons daquele que escrevia, daquele que participava do ato da escrita literária. O direito de estar em todos os lugares é o princípio básico, de acordo com o pensamento blanchotiano, do escritor que precisa se despojar do eu para se tornar ele - aquele que se desdobra em múltiplas categorias do texto que escreve, estando em todo o lugar no instante em que o eu não está.

Sabemos que o narrador já se encontra na posição de personagem de La folie du jour, embora na posição de personagem que narra, e, ao se acreditar somente personagem e náo mais autor do que relata, o narrador se duplica como personagem, bem como se posiciona como o sujeito que não escreveu a narrativa. Essa é uma das interpretações para a negação proferida ao final da obra pelo narrador. A comprovação de sua imersão no que relata é a prestação de contas que a lei exige dele. Se observado bem, o dia, a lei e os médicos são criações do narrador, ou seja, quem exige que o narrador preste contas não é a lei, mas o próprio narrador. Todavia, ele se acreditava, desde então, como personagem do espaço ficcional que originou, não como autor: “É o 'eu' sem 'eu' da voz narrativa, o eu 'despojado' dele mesmo, aquele que não tem lugar, é ele quem lhes dá à luz, quem engendra esses homens da lei lhes dando a ver o que os concerne e não deveria os concernir" 40 .

Em um significativo momento da narrativa La folie du jour, o narrador toca o joelho da lei. Ao tocá-la, o narrador não está tocando somente a lei, personagem de sua criação, mas também a si e a todo o material criado por ele, os médicos, o outro, o casal, a todos: "Ela era nesse meio superpovoado de homens o único elemento feminino. Ela me tinha feito uma vez tocar seu joelho: uma bizarra impressão." ${ }^{41} \mathrm{Em}$ francês, a palavra genou/joelho, como nos lembra Derrida, tem a sonoridade das palavras $j e /$ eu e nous/nós reunidas, o que, a meu ver, afirma a potencialidade da fusão entre o narrador, aquele que diz je, e os demais personagens presentes em La folie du jour, que estáo concentrados no 
espaço do nous. Nesse instante, no estranhamento em tocar o outro, tocando a si mesmo, todos são tocados através do ato de comunhão entre os personagens e seu criador, ambos se veem como seres enclausurados numa mesma perspectiva de escrita - a escrita sem exterior, escrita impossível por ser fragmentada e por estar em fragmentos.

No antepenúltimo fragmento da narrativa blanchotiana se confirma o passo errante do narrador em seu texto sem saída:

\begin{abstract}
Alguém me tinha pedido: Conte-nos como as coisas se passaram "ao certo". - Uma narrativa? Eu comecei: Não sou nem sábio nem ignorante. Conheci alegrias. É muito pouco dizer. Eu lhes contei a história inteira que eles escutavam, me pareceu, com interesse, ao menos no início. Mas o fim foi para nós uma comum surpresa. "Depois deste começo, eles diziam, você passará aos fatos." Como assim! A narrativa estava terminada. ${ }^{42}$
\end{abstract}

A resposta dada ao alguém não identificado revela o desabar da estrutura do discurso elaborado pelo narrador, em que observamos o início do seu primeiro fragmento despencar, sendo deslocado abruptamente para dar ensejo ao fragmento que lemos acima. A primeira frase de La folie du jour é arrastada, passando e destruindo as demais construçóes frasais para poder ser novamente proferida pelo narrador no antepenúltimo fragmento da narrativa. E, desse modo, sendo reconstruída a partir dos pedaços de palavras deixados pela passagem do fragmento inicial. A narrativa blanchotiana se reestrutura a partir de sua ruína. Com a estrutura refeita, passa a ser novamente ruína, movimento errante, movimento repetitivo: "Iteraçáo de uma narrativa contando a si mesma." ${ }^{33} \mathrm{O}$ retorno do "Não sou nem sábio nem ignorante" concede ao texto do personagem uma repetição metalinguística de seu próprio discurso.

No fragmento acima, o que nos é apresentado já foi apresentado, sendo redito em uma perspectiva da repetição que dá o tom da atemporalidade do discurso blanchotiano, pois a repetição se processa a partir da categoria do tempo atual, a partir do presente da enunciaçáo do narrador, náo havendo outra categoria temporal a náo ser a categoria do agora. Categoria que se torna atemporal devido ao caráter imediato do tempo excluir outras instâncias temporais. A narrativa que se elabora no presente é sem exterioridade, pois nada escapa ao agora. O movimento sem exterior é o passo errante dado pelo narrador desde o momento inicial de sua narrativa. Com a leitura do antepenúltimo fragmento, certifica-se que não há e nunca houve saída. No entanto, é nessa (im)possibilidade de saída que o diálogo de La folie $d u$ jour pode se realizar. E mesmo não podendo tocar o fora, $\mathrm{o}$ narrador ainda procura pôr as mãos no impenetrável. É pelo possível impossível que podemos ter em mãos o texto da loucura
42. Ibidem, p. 29.

43. LEVINAS, Emmanuel. Sur Maurice Blanchot, 2004, p. 59. 
44. DERRIDA, Jacques. Parages, 1986, p. 271. Grifos do autor.

45. BLANCHOT, Maurice. La folie du jour, 2002, p. 29. do dia. Derrida, em "La loi du genre", chamará esse movimento errante de invaginação, quando a borda superior da narrativa atinge a sua borda inferior:

Vê-se, sem ver, lê-se o desmoronamento da borda superior ou da borda inicial de La folie du jour desenvolvida segundo a ordem "normal", aquela que rege a lei comum, a convenção editorial, o direito positivo, o regime da competência em nossa cultura logo-alfabética, etc. De repente a borda superior ou inicial, o que se chama a primeira linha de um livro, vem a fazer um bolso no interior do corpus. Ela vem tomar a forma de uma invaginação pela qual o traço da primeira linha, a "borderline" se vocês desejam, se divide permanecendo a mesma e atravessa o corpus que, no entanto, ela margeia. ${ }^{44}$

O processo de invaginação derridiana levará ao que antes comentei sobre a repetição em La folie du jour, pois a invaginação da narrativa produzirá outras múltiplas invaginações no instante em que a arquitetura discursiva do que é relatado passa a ganhar a liberdade errante da narração literária. A precipitação do erro se dará novamente no penúltimo fragmento do texto blanchotiano:

Tive de reconhecer que não era capaz de formar uma narrativa com esses acontecimentos. Tinha perdido o sentido da história, isso acontece em muitas doenças. Mas essa explicação somente os deixou mais exigentes. Percebi então pela primeira vez que eles eram dois, que esse entorse ao método tradicional, embora se explicando pelo fato que um era um técnico da vista, o outro um especialista das doenças mentais, dava constantemente a nossa conversa a característica de um interrogatório autoritário, vigiado e controlado por uma regra estrita. Nem um nem outro, decerto, era o delegado de polícia. Mas, sendo dois, por causa disso eles eram três, e esse terceiro permanecia firmemente convencido, estou seguro disso, que um escritor, um homem que fala e que raciocina com distinção, é sempre capaz de contar fatos dos quais ele se lembra. ${ }^{45}$

No fragmento acima, há algumas questôes importantes a serem comentadas. Agora, não se discute apenas a questão da despersonalização do narrador ao negar ser capaz de escrever uma narrativa com os acontecimentos que lhe ocorreram, bem como acontecimentos que ele narra durante todo o texto. Ao negar, ele nega ser aquele que diz eu no início da narrativa, negando a si mesmo ele nega a narrativa como sua elaboração, embora a narrativa somente se produza a partir do momento em que o narrador diz eu. Derrida levantará a hipótese de multiplicação da voz narrativa, afirmando a possibilidade de existirem vários eu, várias vozes que se complementam ao longo do texto 
de La folie du jour: "aquele que diz 'eu', que não é forçosamente um narrador e não necessariamente o mesmo sempre" ${ }^{46}$. Derrida comentará a dissonância complexa entre o $e u$ do primeiro fragmento e o $e u$ do penúltimo, destacando a impossibilidade de o último se constituir narrador ao negar o primeiro. Compartilho da ideia derridiana; entretanto, acredito numa complexidade ainda maior, na complexidade do neutro. Ao negar ser aquele que diz eu no início da narrativa, ao negar ser instruído, negando que seja um escritor, pois diz não ser capaz de contar os fatos dos quais se lembra, o narrador se inscreve definitivamente no espaço da neutralidade, distanciando-se de qualquer normatização da língua, normatização da cultura. O narrador é a possibilidade de contar os fatos ocorridos a ele sem ser necessariamente um escritor. O narrador é a dispersão, a decadência do dia, é a noite: "Quem eu era? Responder a essa questão me teria lançado em grandes tormentos." ${ }^{47}$

O narrador se afasta da imposição da palavra do mundo, da palavra previamente estabelecida. Ele é a incógnita sem possibilidade de resposta que surge desde o início da narrativa, pois a palavra que nos instrui é incapaz de proferir o que se diz e o que se ouve no espaço da neutralidade. $\mathrm{O}$ narrador-neutro náo é instruído, não é capaz. Ele é a evanescência da possibilidade, é o $\operatorname{sim} . .$. sim..., nem... nem..., não precisando de sentido para existir. A sua fala não possui um único sentido, mas múltiplos, produtividade que se repete, repetindo-se: "utilizando de um neologismo neo-derridiano: o neutro é a ausância de sentido" ${ }^{4}$. No ato de dizer não ao que relatou, o narrador se inscreve também na questáo da autoria levantada por Blanchot no livro $O$ espaço literário - segundo Blanchot, a obra se basta a ela própria, não precisando da autoridade do escritor para sobreviver. Assim, o narrador se afasta da categoria que, logo mais, o seu próprio texto lhe negaria: a categoria de escritor, de detentor do que escreveu, do que proferiu. Por essas razóes, o narrador é o que não pode ser tocado, é o exterior, ele mesmo inatingível. No derradeiro fragmento, lemos a neutralidade de La folie du jour e uma segunda invaginação: "Uma narrativa? Não, não uma narrativa, nunca." ${ }^{49}$

A segunda invaginação ocorre na pergunta "Uma narrativa?”, em que, dessa vez, é o antepenúltimo fragmento que é arrastado para comparecer no último fragmento que acabamos de ler. Dessas duas invaginaçôes, se sobressaem o movimento errante e a impossibilidade de atarmos uma única compreensão para os fatos narrados, uma vez que o texto blanchotiano se hospeda no espaço da neutralidade literária. A impossibilidade de uma única via de acesso à narrativa blanchotiana nos leva, compreensivelmente, à impossibilidade de dizermos onde começa ou termina La folie du jour: "Essa dupla invaginação quiasmática das bordas
46. DERRIDA, Jacques. Parages, 1986, p. 269.

47. BLANCHOT, Maurice. $L a$ folie du jour, 2002, p. 16.

48. BIDENT, Christophe. "Les mouvements du neutre". Revista Alea, 2010, p. 23. Grifos do autor.

49. BLANCHOT, Maurice. La folie du jour, 2002, p. 30. 
50. DERRIDA, Jacques. Parages, 1986, p. 244. impede de discernir na leitura o limite indivisível de um começo e de um fim." 50

Em La folie du jour, não existe fim, como também não existe exterior, saída disponível. A janela continua fechada, e aquele que narra, não sendo o narrador, mas o alguém que se fere com uma faca, que fere os próprios olhos com cacos de vidro, o alguém que pergunta, o homem que cede o passo, o bebê que observa o rosto da máe se direcionar ao rosto do homem estranho, a lei que se faz promíscua, esse alguém sendo o dia tornado noite e a noite tornada luz dispersante, esse não narrador ainda continua lá, olhando para nós, dizendo-se preso no próprio enredo que originou. Essa, definitivamente, é a loucura do dia. 


\section{Referências}

BIDENT, Christophe. "Les mouvements du neutre". Revista Alea, v. 12, n. 01, p. 13-33, jan./jul. 2010.

BLANCHOT, Maurice. Thomas l'obscur. Paris: Gallimard, 1950.

. Le pas au-delà. Paris: Gallimard, 1973.

L'écriture du désastre. Paris: Gallimard, 1980.

O espaço literário. Tradução de Álvaro Cabral. Rio de Janeiro: Rocco, 1987.

La folie du jour. Paris: Gallimard, 2002.

DERRIDA, Jacques. Parages. Paris: Galilée, 1986.

LEVINAS, Emmanuel. Sur Maurice Blanchot. Paris: Fata

Morgana, 2004. 
